\title{
STUDI BAHASA SANSKERTA SEBAGAI METODE BELAJAR AGAMA HINDU
}

\author{
Gede Agus Siswadi \\ Universitas Hindu Negeri I Gusti Bagus Sugriwa Denpasar \\ email : gedeagussiswadi@gmail.com
}

Diterima: 26 Maret 2021, Direvisi : 10 April 2021, Diterbitkan : 27 April 2021

\begin{abstract}
Sanskrit is the language used in the holy Vedic texts. To understand the contents of the Veda, it is very important to learn Sanskrit to know every meaning of the verse or mantra contained in the Veda scriptures. However, the existence of Sanskrit at this time has not been touched at all by Hindus and is very familiar with the use of Sanskrit. Sanskrit is only studied in institutions or colleges with Hindu nuances, so Hindus today have very little to know, let alone learn it. Besides that, Sanskrit is quite complex, there are many rules in learning it, so that Sanskrit is said to be a complex language and difficult to learn. The purpose of this study was to identify and describe an effective and fun method of learning the Sanskrit language. This research method is to use a qualitative descriptive approach. The results of this study are the first, the importance of Sanskrit to be studied by Hindus, because Sanskrit is the language of instruction for the sacred libraries of Hindus, namely Veda and all parts of the veda, besides learning Sanskrit is also an indirect method of understanding. Hindu religious teachings are complex and intact. Second, the Sanskrit language learning method really determines the success of learning, so the learning method needs to be adjusted to the character of the Hindu habit, in addition to using the storytelling method.
\end{abstract}

Keywords : Sanskrit, Hindu learning methods

\section{PENDAHULUAN}

Bahasa Sanskerta adalah bahasa yang digunakan untuk menjelaskan sabda suci (wahyu) dari Brahman atau Ida Sang Hyang Widhi Wasa yang tersurat dalam kitab suci Veda. Veda adalah kitab suci Agama Hindu, semua ajarannya mengalir dari Veda. Bahasa Sanskerta dengan huruf Devanāgarī-nya merupakan satu-satunya sarana yang dapat digunakan untuk mendalami dan menghayati ajaran kitab suci Veda dan sastra lainnya. Dengan demikian bahasa Sanskerta adalah bahasa yang wajib dipelajari sebelum mempelajari Veda, karena tidak akan mungkin memahami isi Veda tanpa mengerti bahasanya (Surada, 2011: 1).

Bahasa Sanskerta merupakan leluhur bahasa Yunani, Romawi, Jerman, Slavia, Polandia, Latin, Inggris dan lain-lain yang termasuk rumpun bahasa Indo-Eropa (Booij, 2007: 99-129). Bahasa Sanskerta pertama kali digunakan oleh bangsa Arya dan tumbuh di sekitar sungai Danao kira-kira di Utara pegunungan Kaukasus. Entah apa yang menyebabkan penutur bahasa ini meninggalkan tempatnya menuju semenanjung Balkan. Selanjutnya mereka menyebar ke Barat dan ke Timur. Yang ke Barat menurunkan bahasa Yunani, Romawi, Jerman, Slavia, dan lain sebagainya, sedangkan yang ke Timur dalam perjalanannya sampai di India (Soetardi, 2001: 1). 
Perkembangan bahasa Sanskerta di India tumbuh dengan pesat. Pada abad VI di India lahir seorang ahli bahasa dunia yang terkenal, yaitu Pāṇini. Beliau dilahirkan di daerah Salatura kerajaan Sandnara yaitu di antara Iran dan Afganistan sekarang. Ia adalah seorang ahli bahasa dunia yang pertama kali menyusun hukum-hukum atau peraturan-peraturan tentang bahasa Sanskerta yang membedakan antara akar kata dan kata, bagaimana cara membentuk pangkal (dasar) kata, apa itu awalan dan akhiran kata, serta dimana kata-kata itu ditempatkan, juga bagaimana cara membedakan akhiran dengan akhir kata dan beberapa kata yang mempunyai akar-akar kata yang sama, serta bagaimana membentuk dan menyusun kata-kata majemuk (Soetardi, 2001: 4).

Buku karangan Pāṇini disebut Aștadhyāȳ̄ yang terdiri dari delapan sūtra/bab dengan 4.000 baris kalimat-kalimat pendek, dan khusus yang mengenai tata bahasa Sankserta diberi judul Pāninińabdānuśasanam. Jejak langkah Pāṇini pada abad III SM diikuti oleh pengikutnya yang bernama Katyayana (Sakatayana). Dan pada abad 150 SM diikuti pula oleh Patañjali dengan menjelaskan masalah Paramaśāstra (Tata Bahasa) dengan judul bukunya adalah "Bhāṣā"(Soetardi, 2001: 4).

Pengaruh bahasa Sanskerta kepada ilmu Bhāṣa terutama di Eropa adalah berkisar kepada bahasa Latin, bahasa Yunani dan bahasa-bahasa Eropa lainnya, dimulai sejak adanya penyelidikan yang dilakukan oleh para sarjana Eropa ke dalam India pada abad ke XVIII antara lain oleh Sir William Jones yang sejak tahun 1783 menjadi hakim dalam benteng yang dinamakan William di Benggala "(Soetardi, 2001: 5).

Sir William Jones yang pertama kali memperkenalkan bahasa Sanskerta melalui sebuah cerita "Sakuntala dan Manu" ke dalam bahasa Inggris kepada dunia luar. Beliau mempunyai pandangan yang baik sekali tentang perimbangan antara bahasa Sanskerta dengan bahasabahasa lain yang serumpun. Dalam pernyataannya yang dikeluarkan pada tahun 1786 antara lain menyebutkan hal-hal sebagai berikut:

"Bahasa Sanskerta mempunyai susunan yang mengherankan, lebih sempurna daripada bahasa Yunani, lebih kaya daripada bahasa Latin dan lebih halus daripada keduanya (Yunani dan Latin). Bahasa ini dengan kedua bahasa itu, baik mengenai akar kata kerja maupun kata bentukan, berada di dalam kekeluargaan yang demikian dekatnya, sehingga tidak mungkin disebabkan oleh sesuatu unsur yang secara kebetulan saja, dan yang demikian nyata, sehingga tiap ahli kesusasteraan harus berpendapat bahwa bahasa-bahasa tersebut (Sanskerta, Yunani dan Latin) berasal dari satu sumber" (Soetardi, 2001: 5-6).

Sebagai bahasa yang lengkap selama beribu-ribu tahun di kalangan masyarakat India, sehingga bahasa Sanskerta dikelompokkan menjadi tiga bagian. Seperti yang dituliskan oleh Schoterman dalam (Collins, 2009: 104) sebagai berikut:

Generally speaking, one may distinguish between three types of Sanskrit: 1) Vedic Sanskrit. 2) Post Vedic Sanskrit following the rules of Pānini, and 3) Post Vedic Sanskrit not strictly following the rules of Pāninin.

Terjemahannya:

'Pada umumnya bahasa Sanskerta dibedakan menjadi tiga bagian: 1) Sanskerta Vedik, 2) Sanskerta Pasca Vedik yang menuruti rumus-rumus Pāṇini dan 3) Sanskerta Pasca Vedik yang tidak dengan tegas menuruti rumus-rumus Pāṇini'.

Lebih lanjut (Winanti, 2004: 2-3) menjelaskan bahwa bahasa Sanskerta memiliki susunan yang lebih rapi dan terang, serta lebih mudah dipisah-pisahkan. Oleh karena itu pada abad XIX bahasa Sanskerta selalu dipelajari oleh ahli bahasa Eropa untuk pemahaman yang lebih jelas dan mendalam tentang bahasa Latin dan Yunani. Dalam perkembangannya, bahasa Sanskerta dikelompokkan menjadi tiga, yaitu (1) Vedic Sanskrit adalah bahasa yang digunakan dalam Veda. Bahasa Sanskerta jenis ini dianggap lebih kuna dan dianggap berhubungan dengan 
semua hal sakral di India karena berkaitan erat dengan pelaksanaan Homa Yajña dan bukubuku Catur Veda ditulis dalam bahasa Sanskerta Veda; (2) Classical Sanskrit adalah bahasa Sanskerta yang dipakai dalam sastra-sastra Hindu dan filsafat yang mulai berkembang abad ke-8 sebelum masehi; dan (3) Hybrida Sanskrit adalah bahasa Sanskerta yang sudah mendapat pengaruh dari bahasa yang berkembang.

Berkembangnya bahasa Sanskerta di Nusantara pada mulanya dibawa oleh para pendeta Hindu dari India dan sekitarnya. Para pendatang dari India ini mulanya datang untuk berdagang, namun dalam perkembangannya terjadilah asimilasi budaya, terutama dalam hal peradaban. Peradaban Hindu sendiri masuk ke Nusantara sekitar abad ke-4 masehi dan berkembang pesat atau mencapai puncak kejayaannya sekitar abad ke-7 masehi. Nampaknya peradaban Hindu-Buddha di masa lampau telah banyak memengaruhi peradaban dan budaya. Dapat dipastikan bahwa sebagian besar bahasa Jawa Kuno banyak dipengaruhi oleh bahasa Sanskerta (Sudrajat, 2012: 1).

Zaman Dharmawangsa Teguh merupakan salah satu tonggak awal bagi kesusasteraan Hindu di Nusantara. Pada abad ke-10 diketahui adanya suatu proyek besar, yaitu Mangjawaken Byasamata atau membahasajawakan ajaran-ajaran Vyasa. Bhagawan Vyasa adalah penulis kitab Mahābhārata. Di samping itu dilakukan pula kegiatan membahasajawakan ajaran-ajaran Walmiki, yaitu Uttarakanda sebagai kanda ketujuh yang membangun Rāmāyaṇa. Raja Dharmawangsa Teguh tampaknya menaruh perhatian besar pada sastra-sastra yang mengandung ajaran agama Hindu (Agastia, 1994: 2).

Dalam perkembangannya bahasa Sanskerta merupakan bahasa identitas Agama Hindu, sebagaimana dalam agama Islam adalah bahasa Arab. Bahasa menunjukkan bangsa. Mantra, Püja, Stāva yang selalu diucapkan oleh rohaniawan Hindu seperti Pandita atau Sulinggih pada saat memimpin acara Yajña menggunakan Püja yang berisi bahasa Sanskerta. Nama-nama orang, bangunan-bangunan masih banyak menggunakan nama bahasa Sanskerta. Saat ini bahasa Sanskerta masih tetap dipakai secara luas sebagai sebuah bahasa seremonial pada upacara-upacara Hindu dalam bentuk stotra dan mantra (Surada, 2012: 3).

Pemahaman ajaran Agama Hindu akan menjadi baik jika bahasa yang digunakan dari sumber ajarannya dapat dimengerti dan dipahami dengan baik. Sumber ajaran Agama Hindu adalah Veda. Mempelajari Agama Hindu tidak akan mungkin tanpa mempelajari kitab Veda dan kitab-kitab susastralainnya, seperti Dharmaśāstra, Itihāsa, Purāṇa dan kitab Vedāńga. Bahasa yang dipergunakan dalam kitab-kitab tersebut adalah bahasa Sanskerta. Dengan demikian pengetahuan tentang bahasa Sanskerta bagi umat Hindu sangat penting (Pudja, 1982: 13). Berdasarkan pernyataan tersebut di atas maka sangat penting untuk kembali mempelajari bahasa Sanskerta untuk mendalami kembali ajaran-ajaran yang terdapat dalam agama Hindu, karena bahasa Sanskerta merupakan akar dalam mendalami ajaran agama Hindu.

Pembelajaran bahasa Sanskerta pada instansi-instansi ataupun perguruan tinggi Hindu dalam hal ini dirasakan kurang maksimal untuk dapat memahami bahasa Sanskerta secara utuh dan komprehensif. Hal tersebut dikarenakan bahasa Sanskerta dikatakan sebagai momok yang menakutkan dan sangat sulit untuk dipelajari, di samping itu untuk memahami bentuk dan konsep Sanskerta harus terlebih dahulu memahami bentuk tata bahasanya, bahasa Sanskerta juga dilengkapi dengan bentuk akar kata, vyākarana dan bentuk-bentuk persandian dalam membentuk kalimat. Namun, sebelum memahami bentuk-bentuk dari tata bahasa, maka sebagai awal dari pembelajaran adalah dengan mengkomunikasikannya, serta dengan metodemetode yang lain untuk memudahkan dalam memahami bahasa Sanskerta tersebut. Dengan demikian penelitian ini berupaya untuk mengkaji terkait dengan metode pembelajaran bahasa Sanskerta untuk mendalami dan memahami konsep-konsep agama Hindu dalam bahasa Sanskerta. 


\section{METODE}

Metode berarti cara yang tepat untuk melakukan sesuatu dengan menggunakan pikiran untuk mencapai tujuan. Metode penelitian adalah cara atau prosedur ilmiah yang diterapkan untuk melaksanakan penelitian. Karya ilmiah tanpa menggunakan metode penelitian yang jelas dan pasti maka nilai ilmiah dari pengetahuan yang diperoleh akan diragukan dan di sangsikan kebenarannya, oleh karena itu di dalam penulisan karya ilmiah tidak semua metode digunakan, hanya beberapa metode dari metode yang ada. Penelitian ilmiah harus dapat dipertanggung jawabkan secara ilmiah pula. Oleh karena itu diperlukan metode penelitian yang jelas dan memadai yang diharapkan mampu mendapatkan data yang akurat (Gulo, 2002: 155).

Pendekatan yang digunakan dalam penelitian ini adalah pendekatan kualitatif. Moleong (2002:3) mengatakan bahwa penelitian kualitatif adalah prosedur penelitian yang menghasilkan data deskriptif berupa kata-kata tertulis atau lisan dari orang yang diamati. Dengan demikian, melalui pendekatan kualitatif akan diproleh data deskriptif, dimana data yang dikumpulkan lebih banyak berupa kata-kata atau gambaran dari pada adat yang berwujud angka. Artinya tidak hanya pada pengumpulan dan penyusun data tetapi juga menganalisis tentang arti data tersebut.

\section{HASIL DAN PEMBAHASAN}

\section{A. Bahasa Sanskerta Sebagai Bahasa Veda}

Suatu bahasa dinamai menurut daerah geografis yang penduduk-penduduknya sebagian berbicara dalam bahasa yang bersangkutan. Misalnya bahasa Inggris adalah bahasa dari Negara Inggris, bahasa Prancis adalah bahasa yang berasal dari Negara Prancis dan bahasa Indonesia adalah bahasa yang berasal dari Negara Indonesia. Tetapi Bahasa Sanskerta sebagaiama sebuah bahasa yang tidak bertalian dengan apapun daerah geografis seperti tersebut. Maka untuk memberi definisi Bahasa Sanskerta adalah berbeda dengan bahasa-bahasa tersebut (Sharma, 1985: 1).

Bahasa Sanskerta berasal dari kata Samskerta bhasa yaitu bahasa yang berbudi/halus (Apte, 2000: 343). Samskerta bhasa adalah bahasa yang halus di pakai untuk menyusun Veda. Penulisan Veda diperkirakan sebelum 2500 Sebelum Masehi. Menurut Kale, (1992: 1) Bahasa Sanskerta adalah sebagai berikut.

Sanskrt, or the refined language, is the language of Devas or Gods, and alphabet in which it is written is called Devanagari or that employed in the cities of Gods.

Bahasa Samskerta atau bahasa yang sopan/halus adalah bahasa dari Deva-Deva atau Tuhan (Daivivak) dan abjadnya ditulis dengan nama huruf Devanagari yang telah dipakai di dalam kota-kota dari Deva atau Tuhan.

Bahasa Sanskerta adalah termasuk rumpun bahasa Indo-Eropa dan merupakan bahasa Indo-Arya Kuno, yang termasuk dalam kelompok Indo-Iranian. Bahasa Indo-Iranian juga merupakan cabang dari rumpun bahasa Indo-Eropa.

Bahasa Sanskerta mempunyai beberapa bentuk yaitu yang dipakai dalam Veda, Kesusastraan Hindu, Sanskerta yang telah menerima pengaruh bahasa lain (Hybrida Sanskrit) dan bahasa Samskerta kepulauan (Archipelago Sanskrit). Dengan perkembangannya yang pesat sesudah diturunkannya Veda kemudian para ahli membedakan Bahasa Sanskerta ke dalam tiga kelompok yaitu:

1. Bahasa Sanskerta Veda (Vedic Sanskrit) yakni bahasa yang digunakan dalam Veda yang umumnya jauh lebih tua dibandingkan dengan Bahasa Sanskerta yang kemudian digunakan berbagai susastra Hindu seperti dalam Itihasa, Purana, Dharmasastra, dan lain-lain. 
2. Bahasa Sanskerta Klasik (Classical Sanskrit) yakni Bahasa Sanskerta yang digunakan dalam susastra Hindu seperti Itihasa (Ramayana dan Mahabharata), Purana (Mahapurana dan Upapurana, Smrti (Kitab-kitab Hukum/ Dharmasastra).

3. Bahasa Sanskerta Campuran (Hybrida Sanskrit) dan Sanskerta di Indonesia oleh para ahli menyebutkan sebagai Archipelago Sanskrit atau Bahasa Sanskerta kepulauan yaitu Bahasa Sanskerta yang digunakan di Indonesia (Astra dkk, 1981: 8).

Tidak bisa dipungkiri bahwa bahasa Sanskerta merupakan bahasa Veda atau bahasa yang digunakan untuk menjelaskan sabda suci Tuhan, sehingga bahasa Sanskerta sangat penting untuk diketahui oleh umat Hindu sebelum mempelajari Veda. Di samping itu semua konsepkonsep yang termuat dalam ajaran agama Hindu bersumber dari bahasa Sanskerta. Dengan demikian, bahasa Sanskerta merupakan bahasa paling awal dan dasar yang harus dikuasai oleh umat Hindu untuk mendalami ajaran-ajaran Veda.

Memahami ajaran Veda dengan memahami bahasa Sanskerta di dalamnya, secara tidak langsung kita sudah melaksanakan salah satu bagian dari Nawa Wida Bhakti yaitu Vedanam yang artinya persembahan yang kita lakukan dengan membaca pustaka-pustaka suci Veda. Dengan demikian, sraddha dan bhakti kita akan menjadi meningkat. Sraddha dan bhakti adalah pondasi yang penting bagi keberlangsungan dan keajegan Hindu sebagai pewaris segala macam bentuk tradisi dan agama Hindu. Untuk itu, sraddha dan bhakti harus ditumbuhkembangkan dalam diri peserta didik, sehingga menimbulkan rasa yakin dan percaya terhadap Ida Sang Hyang Widhi Wasa, terhadap sesama dan lingkungannya (Tri Hita Karana). Sebagaimana penjelasan Smith dalam Sutriyanti (2018: 127) bahwa, agama adalah kebutuhan bagi manusia, karena dengan agama dapat mendekatkan penganutnya dengan Tuhan, dengan bidang sosial, dan alam melalui berbagai bentuk perilaku keberagamaan. Senada dengan itu, Jalaluddin (2011: 223) mendeskripsikan juga hal yang sama dan implisit bahwasanya perilaku keberagamaan akan sangat dipengaruhi iman dan keyakinan penganut agama tertentu akan berbagai bentuk ajarannya.

Lebih lanjut diuraikan, sraddha adalah yang memiliki keyakinan di dalam mempersembahkan upacara pemujaan sebagaimana disebutkan dalam Mantram Atharvaveda VI. 121.3. Penjelasan lebih jauh tentang terminologi kata sraddha dikutip dalam mantram Veda sebagai berikut.

Śraddhāya agnih samidhayte

Śraddhāya huyate havih

Śraddhām bhagaśya murdhani

Vacasa vedayamsi

$$
\text { (Ŗgveda, X, 151. 1) }
$$

Terjemahan:

Api pengorbanan (persembahan) dinyatakan dengan keyakinan yang mantap (sraddha).

Persembahan (korban) dihaturkan keyakinan yang mantap (sraddha). Kami mohon keyakinan yang mantap (sraddha), yang memiliki nilai tertinggi di dalam kemakmuran (Titib, 2006: 167).

Berdasarkan pada uraian tersebut di atas, maka dapat diterminologikan sraddha sebagai sebuah bentuk sikap keyakinan dan kepercayaan kuat yang mengandung kebenaran. Banyak literatur Hindu yang menjelaskan kata sraddha sebagai keyakinan dan kepercayaan yang kuat, salah satunya dalam petikan sloka Bhagavadgita sebagai berikut: 


\section{Śraddhāvat labhate jñanam}

Tatparah samyatendriyah

Jñanam labhdhva param

Śantim acirena dhigacchati

(Bhagavadgita, IV. 39)

Terjemahan:

Ia yang memiliki keimanan yang kuat (sraddha), yang membiarkan diri diresapi kebijaksanaan dan yang telah menghalalkan panca indria mencapai kebijaksanaan dan setelah mencapai itu, ia akan segera mendapatkan kedamaian (Radhakrisnan, 2010: 208).

Merujuk pada hal tersebut, dapat dikemukakan bahwa istilah sraddha adalah merujuk pada pengertian keyakinan yang kuat terhadap ajaran Hindu. Sivananda Swami (2003: 208). Menjelaskan hal yang sama bahwasanya sraddha adalah keyakinan penganut Hindu terhadap ajaran-ajaran yang terdapat dalam pustaka-pustaka suci Veda. Dalam Sutriyanti (2018: 133134) membagi tingkatan bhakti menjadi dua tingkat yaitu apara bhakti dan para bhaktiyang perwujudannya masih lebih rendah, dan umumnya dilakukan oleh mereka yang belum mempunyai tingkat kesucian tinggi dan pemahaman ilu pengetahuan serta kebijaksanaannya belum menonjol. Dalam tingkatan apara bhakti, orang memuja Tuhan dengan penuh pengharapan atau permohonan-permohonan. Sedangkan para bhakti yaitu pemujaan atau bhakti yang dilakukan umat yang tingkat kerohaniannya lebih tinggi. Dimana dalam mewujudnyatakan bhakti-Nya kepada Tuhan, tidak lagi disertai dengan permohonan apapun. Dalam Kitab Bhagavadgita XI. 54 dan IX.26 disebutkan sebagai berikut:

Bhaktyā tv ananyaya á śakya

Aham eva-vidho 'rjuna

Jnātum drastum ca tattvena

Pravestum ca paramtapa

(Bhagavadgita, XI. 54)

Terjemahan:

Tetapi, melalui bhakti yang tak tergoyahkan, aku dapat dilihat dalam realitasnya dan juga memasukinya, wahai penakluk musuh (Arjuna) (Pudja, 2005: 305).

Berdasarkan penjelasan tersebut di atas dapat disimpulkan bahwa pentingnya bahasa Sanskerta untuk dipelajari oleh umat Hindu, karena bahasa Sanskerta merupakan bahasa pengantar dari pustaka-pustaka suci umat Hindu yakni Veda dan seluruh bagian dari veda tersebut, selain itu belajar bahasa Sanskerta juga secara tidak langsung merupakan metode untuk memahami ajaran agama Hindu secara kompleks dan utuh. Di samping itu juga mempelajari bahasa Sanskerta yang merupakan bahasa Veda tersebut juga merupakan implementasi dari Nawa Wida Bhakti, yang salah satunya adalah Vedanam yang artinya persembahan yang dilakukan dengan cara mempeajari pustaka-pustaka suci Veda, dengan demikian sraddha dan bhakti umat Hindu akan lebih meningkat.

\section{B. Metode Belajar Bahasa Sanskerta}

Pembelajaran bahasa Sanskerta pada perguruan tinggi ataupun instansi-instansi yang terdapat muatan bahasa Sanskerta sangat penting untuk menerapkan metode pembelajaran yang efektif dan menyenangkan. Dalam Ambarjaya, Beni (2012: 99) menjelaskan tentang jenis metode pembelajaran, dan di dalam RPKPS Landasan Pendidikan, Neolaka (2015: 121) dijelaskan berbagai jenis metode pembelajaran sebagai berikut: 
1. Metode seminar, kegiatan ilmiah yang dilakukan oleh beberapa orang dalam suatu sidang untuk membahas masalah tertentu dan mencari jalan keluar dari masalah yang dihadapi.

2. Metode kerja kelompok, cara menyajikan bahan pelajaran dengan menugaskan siswa mengerjakan tugas tertentu dalam kelompok untuk membahas topik tertentu.

3. Metode kerja lapangan, metode mengajar dengan membawa siswa ke suatu tempat di luar sekolah, yang bertujuan melakukan observasi dan eksplorasi secara langsung di lapangan.

4. Metode sumbang saran, masalah dikemukakan di kelas dan siswa diminta pendapat dan sarannya.

5. Metode unit teaching, memberikan kesempatan kepada siswa secara aktif dan guru dapat mengenal serta menguasai belajar secara unit.

6. Metode penemuan/discovery, merupakan upaya siswa dalam mengasimilasikan proses atau prinsip-prinsip yang ditemukan dari hasil pembelajaran/hasil penelitian dalam bentuk temuan baru.

7. Metode eksperimen, seorang siswa diajak mengadakan pengamatan yang hasilanya disampaikan di dalam kelas dan dievaluasi oleh guru.

8. Metode sosiodrama dan bermain peran, siswa diajak untuk mendramatisasi tingkah laku atau ungkapan gerak wajah seseorang dalam hubungan sosial antarmanusia.

9. Metode kasus, penyajian pelajaran dengan memanfaatkan kasus yang ditemui siswa sebagai bahan pelajaran. kasus tersebut dibahas bersama untuk mendapatkan jawaban.

10. Metode demonstrasi, dilakukan dengan cara menunjukkan proses tertentu oleh seorang guru.

11. Metode inquiry, teknik pengajaran dengan cara membagi tugas penelitian kelas kepada siswa. Siswa dibagi menjadi beberapa kelompok yang masing-masing mendapatkan tugas tertentu.

12. Metode microteaching, latihan mengajar yang dilakukan oleh siswa dalam beberapa jam mengikuti pola-pola pengajaran tertentu.

13. Metode simulasi, cara mengajar dengan menggunakan tingkah laku seseorang yang bertujuan agar siswa memahami perilaku seseorang yang dimaksudkan dan menirukan karakter orang yang disimulasikan.

14. Metode problem solving, cara mengajar dengan mengetengahkan masalah kepada siswa dan siswa diminta menyelesaikan masalah yang ditawarkan oleh guru.

15. Metode karyawisata, metode mengajar yang dilaksanakan dengan mengajak siswa berdarmawisata, siswa diminta melaporkan hal yang ditemui dan didiskusikan di kelas.

16. Metode dialog, metode pengajaran yang dimulai dengan memberikan pertanyaan, kemudian siswa diminta untuk mengutarakan pendapatnya, sehingga terjadi dialog antarsiswa dan guru atau antarsiswa sendiri.

17. Metode ceramah, cara mengajar yang paling tradisional, efektif untuk jumlah kelas yang besar, dan untuk menjelaskan hal-hal yang baru.

18. Metode diskusi, sering disebut metode diskusi kelompok, cara penguasaan bahan pelajaran melalui diskusi tukar pikiran dan informasi berdasarkan pengetahuan dan pengalaman bagi siswa dalam memahami konsep, menguatkan konsep yang telah dipahami dan memecahkan masalah.

19. Metode cerita, penanaman nilai-nilai kepada siswa dengan mengungkapkan kepribadian tokoh-tokoh melalui cerita rakyat, dongeng sejarah lokal. Digunakan untuk membantu penghayatan nilai, moral dan pembentukan sikap.

20. Metode belajar mandiri, berupa tugas mandiri, seperti: membaca sebuah bab buku dan diringkas, kemudian dipresentasikan di depan kelas, ada diskusi, melakukan penelitian mandiri tanda ada guru pembimbing.

Metode pembelajaran bahasa Sanskerta yang perlu dikembangkan pada perguruanperguruan tinggi, maupun instansi-instansi yang di dalamnya terdapat muatan pembelajaran 
bahasa Sanskerta sangat penting untuk menerapkan pembelajaran yang menyenangkan, hal tersebut karena persepsi umat Hindu tentang bahasa Sanskerta masih sangat dangkal, bahasa Sanskerta dikatakan sebagai bahasa yang mati, atau bahasa yang sulit dipelajari, bahkan bahasa yang tidak lagi digunakan dalam percakapan sehari-hari, sehingga metode belajar bahasa Sanskerta sangat penting untuk diperbaharui, misalnya dengan memberikan metode bercerita, yaitu pengajar dapat memberikan cerita-cerita dalam bentuk dongeng-dongeng lokal yang digubah dengan menggunakan bahasa Sanskerta, seperti cerita yang terdapat di bawah ini:

Ekaḥ kākah āsìt, ekadā saḥ vrkș̣aśākhāyām upaviśati sma, tasya mukhe roțikā āsīt, tadā tatra ekaḥ șrgālah āgacchat, śrgālah kākam avadat "Kākarāja! ekaì gītai் gāya, tava gānam atimadhuram”. muḍhaḥ kākah yadā gìtam agāyat tadā roțikā tasya mukhāt adhah apatat, caturaḥ śrgālaḥ roțikām nītvā tataḥ adhāvat, kākah nirāśa jātaḥ.

Terjemahan:

Ada seekor burung Gagak. Suatu kali, dia hinggap di pohon. Dia memiliki (sepotong) roti di mulutnya. Kemudian, seekor Rubah datang ke sana. Katanya pada Gagak, "wahai gagak! nyanyikan sebuah lagu. lagumu sangat merdu". begitu burung gagak yang bodoh mulai bernyanyi, roti itu jatuh dari mulutnya. Rubah yang pandai mengambil roti dan berlari dari sana. Gagak dibiarkan kecewa.

Bakasya șrrgālasya ca mitratā asti, ekadā șrgālah bakam bhojanārtham svagrham

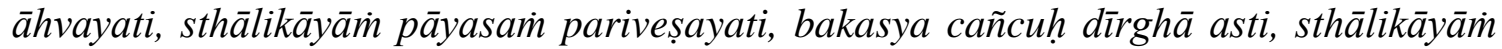
pariveșitam pāyasam bakah khāditum na śaknoti, śrgālah tasya upahāsam karoti, punah kadācit bakaḥ șrgālam bhojanārthaì svagrham āhvayati, tadā sặ galantikāyām pāyasam pariveșayati, galantikāyām pariveșitam pāyasam śrgālaḥ na śaknoti, bakah tasya upahāsam karoti, śrgālaḥ avagacchati, "mama pūrvakr̦tasya etat phalam” iti, saḥ mitrasya kṣamāim prārthayate tayoḥ maitrī drụ̂hā bhavati.

Terjemahan:

Rubah dan Bangau adalah teman. Suatu hari, Rubah mengundang Bangau ke rumahnya untuk makan. rubah menyajikan hidangan di atas piring. Paruh bangau itu panjang, dia tidak bisa makan hidangan yang disajikan di atas piring. Rubah mengolok-oloknya. Suatu hari, Bangau mengundang Rubah ke rumahnya untuk makan. Kemudian dia melayani dan menyajikan hidangan pada tempat yang cocok bagi berleher sempit. Rubah tidak bisa memakan hidangan yang disajikan itu. Bangau mengolok-oloknya. Rubah mengerti, "itu adalah hasil dari perbuatan masa laluku". Dia meminta maaf kepada temannya. Persahabatan mereka menjadi kuat.

Ekasmin vane kaścana vṛkṣaḥ āsīt, tasmin ekaḥ nị̣aḥ āsīt, tatra kaścana cațakaḥ patnyā saha avasat, kadācit atīva vrșțtih āsìt, tadā kaścana vānarặ tatra āgacchat, tasya śarīraì vrșțā klinam āsīt, ātmānam rakșitum saḥ vānarah vṛkșasya upari āgacchat, tadā cațaka

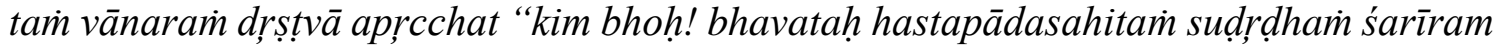
asti, tathāpi ekam grham nirmātum na śaknoti kim?" tat śrutvā kupitah vānarah avadat, "re adhame! mama vișaye bhavatyāh kā cintā?" parantu cațakā punặ tathaiva upadeśam akorat, ante antyantai் kupitạ̣ vānarah cațakāyāh nị̣̄am nāśitavān.

Terjemahan:

Suatu hari di sebuah hutan, ada pohon. ada sarang di atas pohon. di sana, seekor burung tinggal bersama istrinya. Suatu hari, hujan deras. Seekor monyet datang ke sana. tubuhnya basah karena hujan. untuk melindungi dirinya sendiri, monyet itu datang ke puncak pohon. Kemudian burung itu, ketika melihat monyet itu berkata, "hei! kamu memiliki tubuh yang 
sehat dengan tangan dan kaki, mengapa kamu tidak bisa membangun rumah?" Mendengar ini, si monyet yang marah berkata, "Dasar bodoh! kenapa kamu mengkhawatirkan keadaanku?" tetapi burung itu terus memberi saran yang sama kepada monyet. Pada akhirnya, monyet yang sangat marah menghancurkan sarang burung itu.

Selain dapat diberikan cerita-cerita yang bersifat dongeng, dapat juga diberikan ceritacerita yang bersifat sejarah, seperti salah satunya dengan salah satunya seperti cerita yang berkaitan dengan sejarah pura Besakih sebagai berikut:

Bhāratavarse ekah Prasiddhah Mahārșih āsīt tasya nāma Markaṇdeya-mahārșih. Tasya samīpe brhatāśramaḥ āsīt. Agre tam āśramam tasya vamśajāh cālitavantah. Sanātanadharma-prasaranārtham ete Markandeya-vamśajāh sarvatra lokeșu ațanam kurvanti sma. Ekadā teșām niścitam āsìt yat Sanātanadharma-prasaranārtham Bālīdvīpam iti viśesasthānam gamiṣyanti iti. Prāyah aṣtasahasra śiṣyāh Bhāratavarsāt naukābhih prasthānam krtavantah. Kalinggabālīyātrā iti teșam prakalpaḥ āsìt. Kālah gatah te sarve Nusantara-deśam prāptavantantah. Kincit kālaḥ te sarve Javadvīpe sthitvā tatah Bālìdvīpam pratiyāgatavantah. Tasmin samaye Bālìdvīpe mahat aranyam eva āsìt. Tatra bahavah kruramrgāḥ āsan api ca tatra vanavāsinah āsan. Tatra gatvā te sarve vāsārtham aranyasya chedanam arambham krtavantah. Kintu kașta-prakrteh karanena bahavaḥ śisyāh mṛtāh abhavan. Tām sthitim dṛștvā ekah jyeștah pramukhah punah Javadvīpam gatavān. Javadvīpam āgatyā Paśupati-rșinā Saha militvā tasya vișayasya carcām krtavān. Paśupati-rșeh nirdisāt Markaṇdeya-gotrah Semeru-parvate dhyānam krtavān. Dhyāna-samaye kaścana śabdaḥ āgatah, "Bhoh yadi Bālīdvīpam ușitum icchati tarhi tatra ekadasarudrayāgah karanīyaḥ” iti. Tam śabdam anusrtyā saḥ Markandeyagotrah punaḥ catuśata-síşyaị saha Bālīdvīpam āgatavān. Bālīdvīpam āgatyā Tohlangkir-parvatasya adhạ̣ tatra te ekadaśarudra-yāgam krtavantah. Tasmāt eva Bālīdvīpe vāsārtham kartum śaktavantah api Sanātanadharma-samsthāpanasya ārambhah abhavat. Yāgasya sthanāya "Vasukih" iti nāma dattam. Adya Besakih Mandiram iti janāh ș̣nuvanti, iti itihasena uktam. Dhanyavādah.

Terjemahan:

Di Negeri Bhāratam ada seorang Mahārși yang terkenal. Dia bernama Mahārși Markandeya. Dia punya āśrama besar. Selanjutnya āśrama itu dijalankan oleh muridmuridnya. Untuk menyebarkan Sanātanadharma ini keturunan Markandeya kemana-mana berkeliling dunia. Suatu saat mereka sepakat utuk pergi menyebarkan sanātana dharma kepulau Bali inilah tempat yang spesial. Kira-kira 8000 murid-muridnya dari negri Bharata berangkat dengan perahu. Perjalanan mereka dikenal dengan nama Kalingga bālīyātrā. Waktu berlalu mereka sampai di Negeri Nusantara. Beberapa waktu tinggal di Pulau Jawa kemudian langsung pergi ke Pulau Bali. Waktu itu di Bali yang ada hanya hutan lebat. Di sana banyak binatang buas dan orang-orang pedalaman. Setibanya di sana, mereka mulai merabas hutan untuk mendirikan pemukiman. Tetapi karena kesulitan dan banyak para murid-murid tersebut mati. Melihat keadaan itu ketua pimpinan dari keturunan Markandeya kembali berangkat ke Pulau Jawa. Sampai di Pulau Jawa bertemu dengan Mahārși Pasupati membicarakan persoalan itu. Dari petunjuk Mahārși Pasupati keturunan Mahārși Markandeya ini bertapa di Gunung Semeru. Saat bermeditasi datanglah suara bahwa kalau ingin tinggal di Bali maka harus melakukan yajna ekadasarudra. Mengikuti suara tersebut dia keturunan Markandeya pergi dengan 400 murid-murid datang ke Pulau Bali. Setibanya mereka di bawah Gunung Agung, mereka melaksanakan yajna ekadasarudra. Karena itulah bisa untuk tinggal di Pulau Bali juga 
peletakan sanatanadharmah telah dimulai. Tempat yajnya itu dinamai Vasuki yang sekarang dikenal sebagai Pura Besakih. Demikian yang dikatakan sejarah.

Metode pembelajaran bahasa Sanskerta sangat menentukan keberhasilan dari pembelajaran, sehingga metode pembelajaran perlu untuk disesuaikan dengan karakter dari habit umat Hindu, selain menggunakan metode bercerita. Dengan menggunakan metode bercerita menggunakan bahasa Sanskerta, maka secara tidak langsung para peserta didik akan mendengarkan secara langsung dan mencermati kosakata yang terdapat pada cerita tersebut, selain itu terdapat nilai-nilai pendidikan yang terdapat pada cerita tersebut. Metode yang lainnya juga dapat digunakan sebagai bentuk adaptif terhadap pembelajaran. Dengan demikian, pemahaman umat Hindu tentang bahasa Sanskerta akan menjadi lebih baik, serta pemahaman umat Hindu tentang ajaran-ajaran agama yang termuat dalam susastra suci dapat berkembang dengan baik.

\section{KESIMPULAN}

Memahami ajaran Veda dengan memahami bahasa Sanskerta di dalamnya, secara tidak langsung kita sudah melaksanakan salah satu bagian dari Nawa Wida Bhakti yaitu Vedanam yang artinya persembahan yang kita lakukan dengan membaca pustaka-pustaka suci Veda. Metode pembelajaran bahasa Sanskerta yang perlu dikembangkan pada perguruan-perguruan tinggi, maupun instansi-instansi yang di dalamnya terdapat muatan pembelajaran bahasa Sanskerta sangat penting untuk menerapkan pembelajaran yang menyenangkan, hal tersebut karena persepsi umat Hindu tentang bahasa Sanskerta masih sangat dangkal, bahasa Sanskerta dikatakan sebagai bahasa yang mati, atau bahasa yang sulit dipelajari, bahkan bahasa yang tidak lagi digunakan dalam percakapan sehari-hari, sehingga metode belajar bahasa Sanskerta sangat penting diadaptif dengan karakter serta kebutuhan dari pembelajaran.

\section{DAFTAR PUSTAKA}

Agastia, IBG. (1994). Ida Pedanda Made Sidemen Pengarang Besar Bali Abad ke-20. Denpasar: Yayasan Dharma Sastra Denpasar.

Apte, Vaman Shivram. (2000). The Practical Sanskrit English Dictionary. Motilal Banarsidass Publisherr. Private Limited. Delhi.

Astra, I Gde Semadi, Dkk. (1981). Bahasa Sanskerta I. Jakarta: Proyek Pembinaan Mutu Pendidikan Agama Hindu dan Buddha Departemen Agama RI.

Beni. S, Ambarjaya. Psikologi Pendidikan dan Pengajaran, Teori dan Praktik. Jakarta: CAPS, Cempaka Putih.

Booij, Greet. (2007). The Grammar of Word, An Introduction to Linguistic Morphology. Second Edition. Okford University Press.

Collins, James T. (2009). Bahasa Sanskerta dan Bahasa Melayu. Bogor: Grafika Mardi Yuana. Gulo, W. (2002), Metodelogi Penelitian. Jakarta: PT Grasindo.

Jalaluddin, Rakhmat. (2011). Psikologi Agama. Bandung: PT Remaja Rosdakarya.

Kale, M.R. (1992). A Higher Sanskrit Grammar (For the Use of School \& College Student). India: Motilal Banarsidass Publisherr. Private Limited. Delhi.

Moleong, Lexy J. (2002). Metodologi Penelitian Kualitatif. Remaja Rosdakarya: Bandung.

Neolaka, Amos. (2015). Rencana Program Kegiatan Pembelajaran Semester (RPKPS/SAP)Landasan Pendidikan. Jakarta: PPS UKI.

Pudja, I Gde. (1982). Pedoman Khusus Bidang Studi Bahasa Sanskerta. Jakarta: Proyek Pembinaan Mutu Pendidikan Agama Hindu dan Budha Departemen Agama RI.

Pudja, I Gde. (2005). Bhagavad Gita (Pancama Veda). Surabaya: Paramita.

Radhakrishnan, S. (2010). Kitab Bhagavad Gītā: Saripati Falsafah Bijak MahabharataRamayana. IRCiSoD: Yogyakarta. 
Sharma, Makunda Madhawa. (1985). Unsur-unsur Bahasa Sanskerta dalam Bahasa Inonesia. Denpasar: Wyasa Sanggraha.

Sivananda, Sri Svami. (2003). Intisari Ajaran Hindu. Surabaya. Paramita.

Soetardi. (2001). Vyākarana Tata Bahasa Sanskerta. Surabaya: Paramita.

Sudrajat. (2012). Diktat Kuliah Sejarah Indonesia Masa Hindu Budha. Yogyakarta: Pendidikan Sejarah UNY.

Surada, I Made. (2011). Studi Etnografi Pembelajaran Bahasa Sanskerta di Perguruan Tinggi Agama Hindu di Bali. (Usulan Proposal Penelitian). Denpasar: Institut Hindu Dharma Negeri Denpasar.

Surada, I Made. 2012. Studi Pembelajaran Bahasa Sanskerta di Perguruan Tinggi Agama Hindu di Provinsi Bali. Disertasi tidak diterbitkan. Universitas Hindu Indonesia. Denpasar.

Sutriyanti, Ni Komang. (2018). Penumbuhkembangan Karakter dalam Keluarga Hindu di Desa Bayunggede Sebagai Desa Kuno di Bali. Denpasar: Jayapangus Press.

Titib, I Made. (2006). Veda Sabda Suci Pedoman Praktis Kehidupan. Surabaya: Paramita.

Winanti, Ni Putu. (2004). Pengenalan Dasar dan Tuntunan Praktis Bahasa Sanskerta dan Huruf Dewanagari. Surabaya: Paramita. 